\title{
Effects of Shade on Nitrogen and Phosphorus Acquisition in Cereal-Legume Intercropping Systems
}

\author{
Meighen Whitehead and Marney E. Isaac* \\ Department of Physical and Environmental Sciences, University of Toronto, 1265 Military Trail, \\ Toronto, ON M1C 1A4, Canada; E-Mail: meighen.whitehead@utoronto.ca \\ * Author to whom correspondence should be addressed; E-Mail: marney.isaac@utoronto.ca; \\ Tel.: +1-416-287-7276; Fax: +1-416-287-7279.
}

Received: 8 December 2011; in revised form: 12 January 2012 / Accepted: 12 January 2012 / Published: 19 January 2012

\begin{abstract}
With increasing economic and environmental costs associated with fertilizer use, the need for low-input agroecological systems is on the rise. It is well documented that intercropping legumes can increase the supply of nutrients, through $\mathrm{N}_{2}$-fixation and $\mathrm{P}$ mobilization. Concurrently, the integration of trees in the agricultural landscape shows increasing evidence of nutrient inputs through efficient biogeochemical cycles. However, little is known about the effects shade has on legume-crop performance. This research aims to determine whether intercropping of the legumes soybean (Glycine max L. Merr.) and alfalfa (Medicago sativa) with wheat (Triticum turgidum durum) is beneficial for performance, particularly under shady conditions associated with tree-based intercropping. Test species were cultivated in hydroponics with a broad nutrient solution and steady state addition of $\mathrm{N}$ for 3 weeks. Individual plants were transferred to rhizoboxes with a $2 \mathrm{~mm}$ zone of soil for 16 days under (i) full sun or (ii) shade to mimic light levels at the tree-crop interface. Under monocropping, shading was found to significantly decrease wheat biomass. Intercropping wheat with alfalfa under full sun had no negative effect on growth but did increase wheat $\mathrm{P}$ uptake as compared to monocropped wheat. In contrast, intercropping wheat with soybean under full sun decreased wheat biomass, suggesting competition. However, under shade, this competitive effect was mitigated, as wheat exhibited similar biomass and higher $\mathrm{N}$ and $\mathrm{P}$ shoot concentration when associated with soybean as compared to monocropped wheat under lower light levels. This effect may be attributed to reduced biomass of soybean combined with higher soybean $\mathrm{N}_{2}$-fixation under shade. Legume-based intercrops may increase nutrient supply and growth but these
\end{abstract}


beneficial effects will be dependent on matching species selection to light levels under tree-based intercropping.

Keywords: intercropping; ${ }^{15} \mathrm{~N}$ natural abundance; $\mathrm{N}_{2}$-fixation; Ontario; rhizobox; shade effects

\section{Introduction}

As conventional agriculture systems become dominated by monospecific crops, nutrient cycles become more open and therefore more susceptible to losses through leaching, run off and volatilization [1-3]. It is therefore vital that sustainable agriculture practices be developed to decrease inputs of synthetic fertilizers into ecosystems. Intercropping annual crops within tree-based systems can reduce nutrient leaching and increase nutrient cycling, through complementarity of resource partitioning [1,4-6]. This in turn can decrease the amount of external fertilizer inputs.

In single species cropping systems, individuals can be expected to have adapted similar strategies to fulfill those requirements, whereas plants in a multi-species system can have different resource requirements, and possess different biological and physical strategies for acquiring nutrients [7,8]. More specifically, intercropping legumes with non-legumes typically exhibits a nutrient advantage [9-11]. Sierra and Nygren [12] used ${ }^{15} \mathrm{~N}$ natural abundance to demonstrate direct transfer of $\mathrm{N}$ from the legume tree Gliricidia sepium to nearby grass. Other studies have exhibited N transfer from peanut to rice [13] and soybean to maize [14]. Jensen [15] demonstrated a yield increase in intercropped field pea and barley due to complimentary use of soil inorganic and atmospheric fixed $\mathrm{N}$ sources. Li et al. [16] examined phosphorus (P) dynamics in common bean and wheat to elucidate whether rhizosphere acidification from common bean would mobilize $\mathrm{P}$, and thereby benefit intercropped durum wheat. Several studies have investigated the effects of nutrient deficiency on $\mathrm{N}_{2}$-fixation rates. For example, Høgh-Jensen et al. [10] examined the effects of $\mathrm{P}$ deficiency on growth and $\mathrm{N}_{2}$-fixation in white clover plants, and showed that although $\mathrm{P}$ deficiency did not affect $\mathrm{N}$ uptake, it did affect the relative growth of roots, shoots and nodules. Low $\mathrm{P}$ supply also decreased the $\mathrm{N}_{2}$-fixation per unit weight [10].

The effects of light availability on $\mathrm{N}_{2}$-fixation are less certain. Studies have suggested that competition for light can decrease $\mathrm{N}_{2}$-fixation by decreasing growth. Carlsson et al. [17] found that competition for light from grasses may have decreased plant growth and consequently limited $\mathrm{N}_{2}$-fixation at the plant level. Jensen [15] reported that competition from barley had a negative effect on $\mathrm{N}_{2}$-fixation of intercropped pea, also presumably because of increased competition for light. As annual intercrops are increasingly found in tree-based intercropping systems, the effects of light dynamics on biogeochemical processes are emerging as an important interaction.

The objective of this research is to investigate the effects of a low light environment on nutrient dynamics and biomass response of intercropped durum wheat (Triticum turgidum durum) with legumes (Glycine max L. Merr. and Medicago sativa) in order to mimic the tree-crop interface. We employ hydroponically grown legumes and wheat under steady-state $\mathrm{N}$ supply transferred to rhizoboxes under varying light levels. We hypothesize that wheat growth will be suppressed under shade but nutritional status will be enhanced under intercropping, a result of legume-driven rhizosphere effects. However, shade and nutrient effects on isotopic-determined biological $\mathrm{N}$ fixation 
remain uncertain. Uncovering abiotic stresses in this model tree-crop interface provides unique management information in a tree-based intercropping context.

\section{Results}

Wheat performance was highest under full sun in monocropping; dry weight of shoot, root, and total wheat biomass was significantly greater in full sun as compared to under shade (shoot: $p=0.024$; root: $p=0.0441$; total biomass: $p=0.0274$; Table 1 ). Intercropped with soybean under the no shade treatment, wheat shoot mass was significantly smaller $(p=0.042)$ as compared to monocropped wheat (Table 1). However, overall, this significant negative intercropping effect on companion wheat was not observed when intercropped with alfalfa (Table 1). Biomass allocation patterns were confirmed with analysis of the root area. Exclusively in full sun, wheat root surface area was significantly smaller under intercropping as compared to monocropped wheat, decreasing by $20 \%$ when intercropped with alfalfa and $42 \%$ when intercropped with soybean (Table 2). Again, only in full sun, wheat total root length was significantly reduced under intercropping (reduced root length by $26 \%$ when intercropped with alfalfa and reduced root length by $39 \%$ when intercropped with soybean). No significant differences were found between wheat root length and area for intercropping and monocropping when under shade, nor did we measure any changes in the root system of the associated legumes under shade or under no shade (Table 2).

Table 1. Biomass means $( \pm \mathrm{SE})$ for shoot and root tissue and shoot: root for monocropping and intercropped wheat under shade and no shade.

\begin{tabular}{|c|c|c|c|c|}
\hline & \multicolumn{4}{|c|}{ Biomass (g plant ${ }^{-1}$ ) } \\
\hline & Shoot & Root & Total biomass & Shoot: root \\
\hline Design & \multicolumn{4}{|c|}{ Shade } \\
\hline $\begin{array}{l}\text { Monocropping } \\
\text { Intercropping }\end{array}$ & $0.35 \pm 0.063 \mathrm{az}$ & $0.89 \pm 0.089 \mathrm{az}$ & $1.25 \pm 0.152 \mathrm{az}$ & $0.39 \pm 0.034 \mathrm{az}$ \\
\hline $\begin{array}{l}\text { w/ soybean } \\
\text { w/ alfalfa }\end{array}$ & $\begin{array}{l}0.32 \pm 0.019 \mathrm{az} \\
0.37 \pm 0.049 \mathrm{az}\end{array}$ & $\begin{array}{l}0.81 \pm 0.055 \mathrm{az} \\
1.05 \pm 0.043 \mathrm{az}\end{array}$ & $\begin{array}{l}1.13 \pm 0.073 \mathrm{az} \\
1.42 \pm 0.087 \mathrm{az}\end{array}$ & $\begin{array}{l}0.40 \pm 0.007 \mathrm{az} \\
0.35 \pm 0.037 \mathrm{az}\end{array}$ \\
\hline w/ alfalfa & \multicolumn{4}{|c|}{ No Shade } \\
\hline $\begin{array}{l}\text { Monocropping } \\
\text { Intercropping }\end{array}$ & $0.65 \pm 0.046$ ay & $1.32 \pm 0.145$ ay & $1.97 \pm 0.190$ ay & $0.50 \pm 0.025 \mathrm{az}$ \\
\hline $\begin{array}{l}\text { w/ soybean } \\
\text { w/ alfalfa }\end{array}$ & $\begin{array}{c}0.36 \pm 0.006 \mathrm{bz} \\
0.60 \pm 0.073 \mathrm{abz}\end{array}$ & $\begin{array}{l}1.00 \pm 0.083 \mathrm{az} \\
1.37 \pm 0.126 \mathrm{az}\end{array}$ & $\begin{array}{l}1.37 \pm 0.089 \mathrm{az} \\
1.97 \pm 0.143 \mathrm{ay}\end{array}$ & $\begin{array}{l}0.36 \pm 0.023 \mathrm{az} \\
0.44 \pm 0.063 \mathrm{az}\end{array}$ \\
\hline
\end{tabular}

Means within a column for Design with the same letter (a-b) are not significantly different according to a Tukey's test at $p<0.05(\mathrm{~N}=3)$; Means within a column for Shade with the same letter $(\mathrm{z}-\mathrm{y})$ are not significantly different according to a Tukey's test at $p<0.05(\mathrm{~N}=3)$. 
Table 2. Root growth parameters (root surface area and root length) for wheat (in moncropping or intercropped with soybean or alfalfa), soybean and alfalfa.

\begin{tabular}{|c|c|c|}
\hline & \multicolumn{2}{|c|}{ Rhizosphere Parameter } \\
\hline & Root surface area $\left(\mathrm{cm}^{2}\right)$ & Root length $(\mathrm{cm})$ \\
\hline Design & \multicolumn{2}{|l|}{$\begin{array}{ll}\text { Shade }\end{array}$} \\
\hline \multicolumn{3}{|l|}{ Wheat } \\
\hline Monocropping & $63.8 \pm 6.7 \mathrm{az}$ & $799.7 \pm 95.5 \mathrm{az}$ \\
\hline Intercropped w/soybean & $54.9 \pm 6.0 \mathrm{az}$ & $667.4 \pm 89.0 \mathrm{az}$ \\
\hline Intercropped w/alfalfa & $65.5 \pm 5.8 \mathrm{az}$ & $796.2 \pm 71.1 \mathrm{az}$ \\
\hline \multicolumn{3}{|l|}{ Associated legume } \\
\hline Soybean & $24.0 \pm 3.3 \mathrm{z}$ & $350.8 \pm 60.3 \mathrm{z}$ \\
\hline \multirow[t]{2}{*}{ Alfalfa } & $17.2 \pm 2.4 \mathrm{z}$ & $252.7 \pm 36.2 \mathrm{z}$ \\
\hline & \multicolumn{2}{|c|}{ No Shade } \\
\hline \multicolumn{3}{|l|}{ Wheat } \\
\hline Monocropping & $94.8 \pm 17.2 \mathrm{az}$ & $1101.7 \pm 165.7$ ay \\
\hline Intercropped w/soybean & $54.9 \pm 3.7 \mathrm{bz}$ & $672.8 \pm 71.1 \mathrm{bz}$ \\
\hline Intercropped w/alfalfa & $75.6 \pm 0.7 \mathrm{bz}$ & $810.2 \pm 12.1 \mathrm{bz}$ \\
\hline \multicolumn{3}{|l|}{ Associated legume } \\
\hline Soybean & $24.3 \pm 4.1 \mathrm{z}$ & $366.0 \pm 47.8 \mathrm{z}$ \\
\hline Alfalfa & $12.8 \pm 1.7 \mathrm{z}$ & $194.9 \pm 26.2 \mathrm{z}$ \\
\hline
\end{tabular}

Means within a column for Design with the same letter $(a-b)$ are not significantly different according to a Tukey's test at $p<0.05(\mathrm{~N}=3)$; Means within a column for Shade with the same letter $(\mathrm{z}-\mathrm{y})$ are not significantly different according to a Tukey's test at $p<0.05(\mathrm{~N}=3)$.

\subsection{Nutrition}

There was a significant difference in shoot $\mathrm{N}$ concentration between intercropped wheat and wheat in monoculture in the shade treatment ( $p=0.0181$; Figure 1). In comparison to the monocropped wheat treatment, the shoot $\mathrm{N}$ concentration of wheat increased by $72 \%$ and $58 \%$ in the soybean and alfalfa intercropping systems, respectively. The percentage of $\mathrm{N}$ derived from atmosphere (Ndfa), measured by the natural abundance method, in soybean tended to be higher and more consistent under shade (56-73\%), whereas Ndfa in alfalfa ranged from 18\% to $29 \%$ in shade (Figure 2). We detected significantly higher wheat $\mathrm{P}$ concentration when intercropped with alfalfa in the no shade treatment ( $p=0.0094$; Figure 3$)$ and this translated into significantly greater wheat biomass associated with alfalfa over the association with soybean (Table 1). 
Figure 1. Nitrogen concentration (\%) of wheat shoots for monocropped wheat and wheat intercropped with soybean and alfalfa under shade and no shade. Bars represent SE of the means $(\mathrm{N}=3)$.

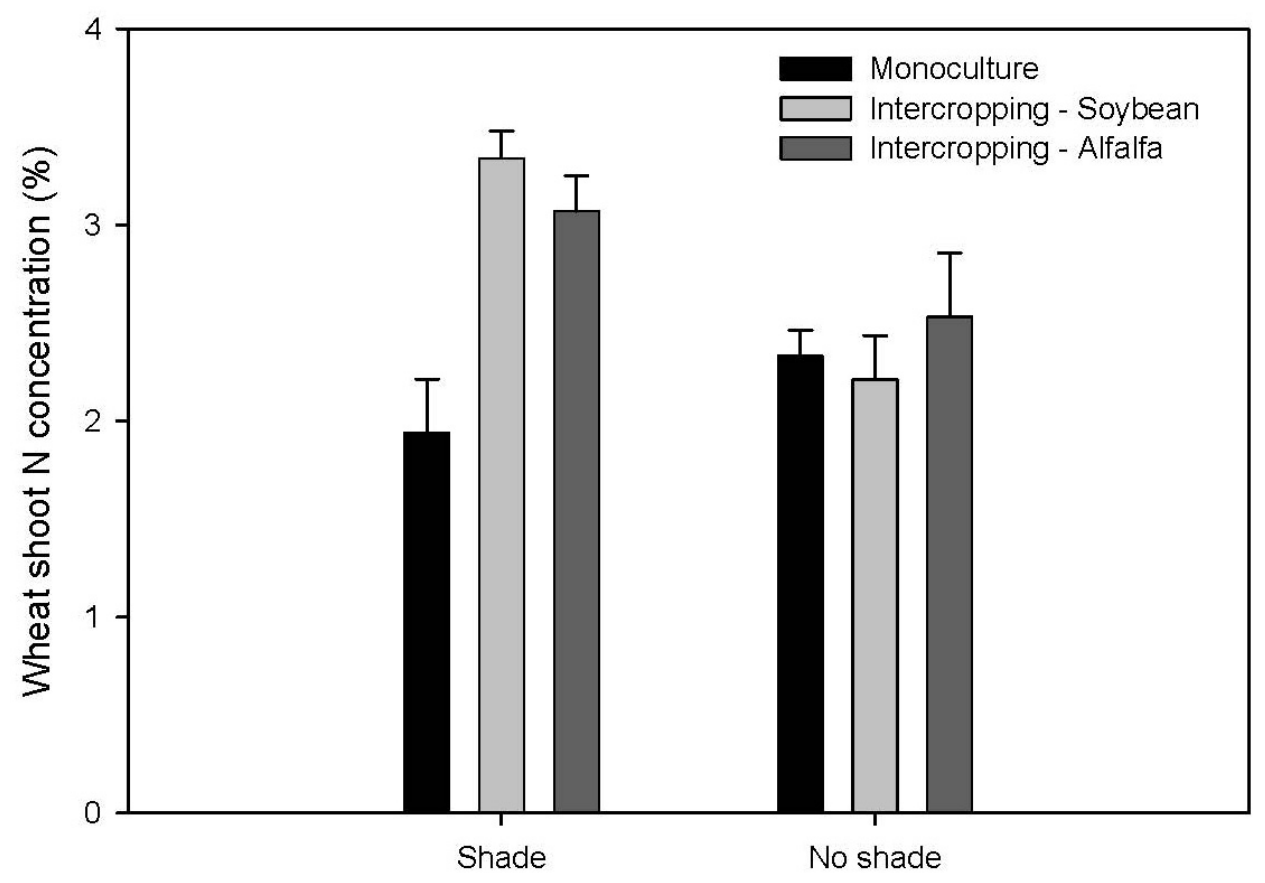

Figure 2. $\% \mathrm{~N}$ derived from atmosphere $(\mathrm{Ndfa})$, determined with the natural abundance method, for soybean and alfalfa in hydroponic systems under shade and in full sun. Bars represent $\mathrm{SE}$ of the mean $(\mathrm{N}=3)$.

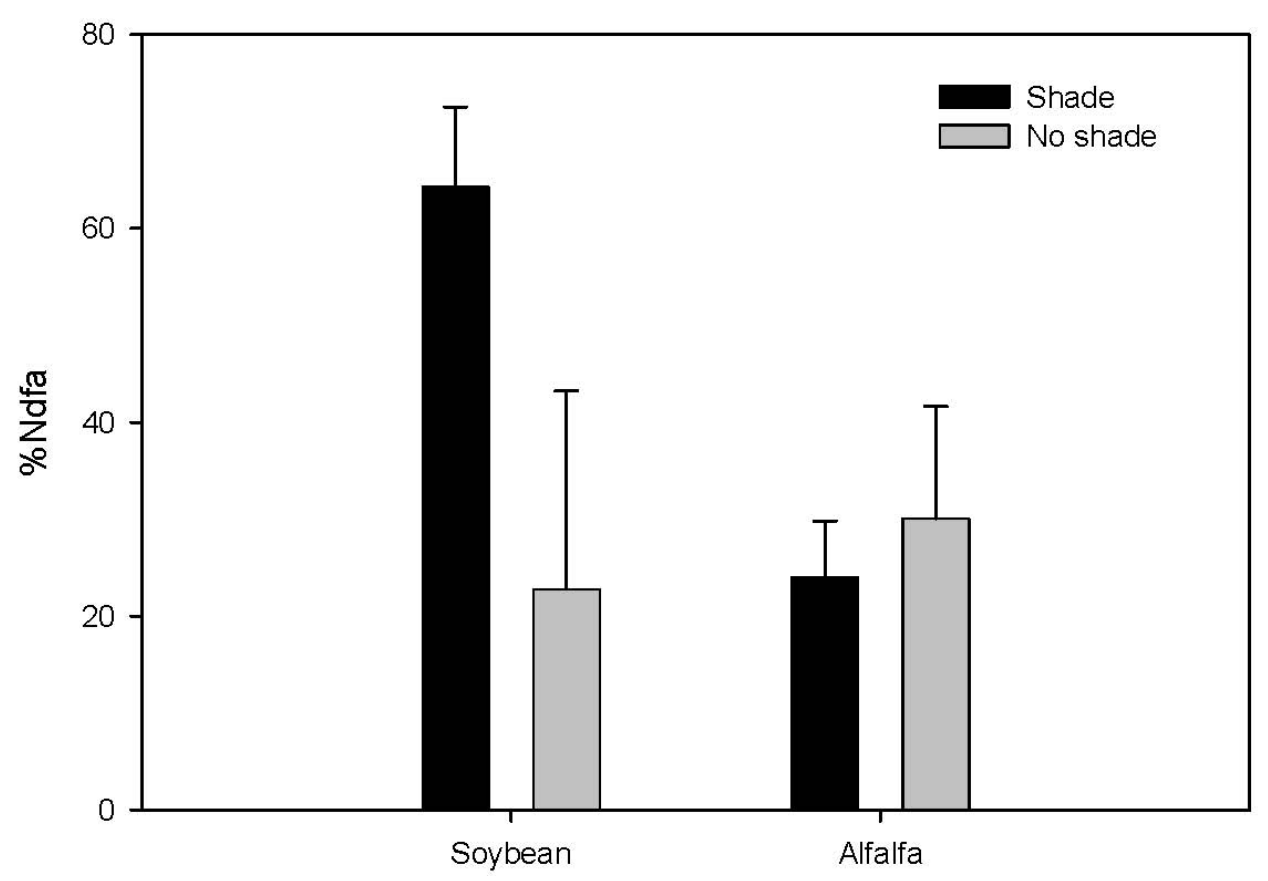


Figure 3. Phosphorus concentration (\%) of wheat shoots for monocropped wheat and wheat intercropped with soybean and alfalfa under shade and no shade. Bars represent SE of the means $(\mathrm{N}=3)$.

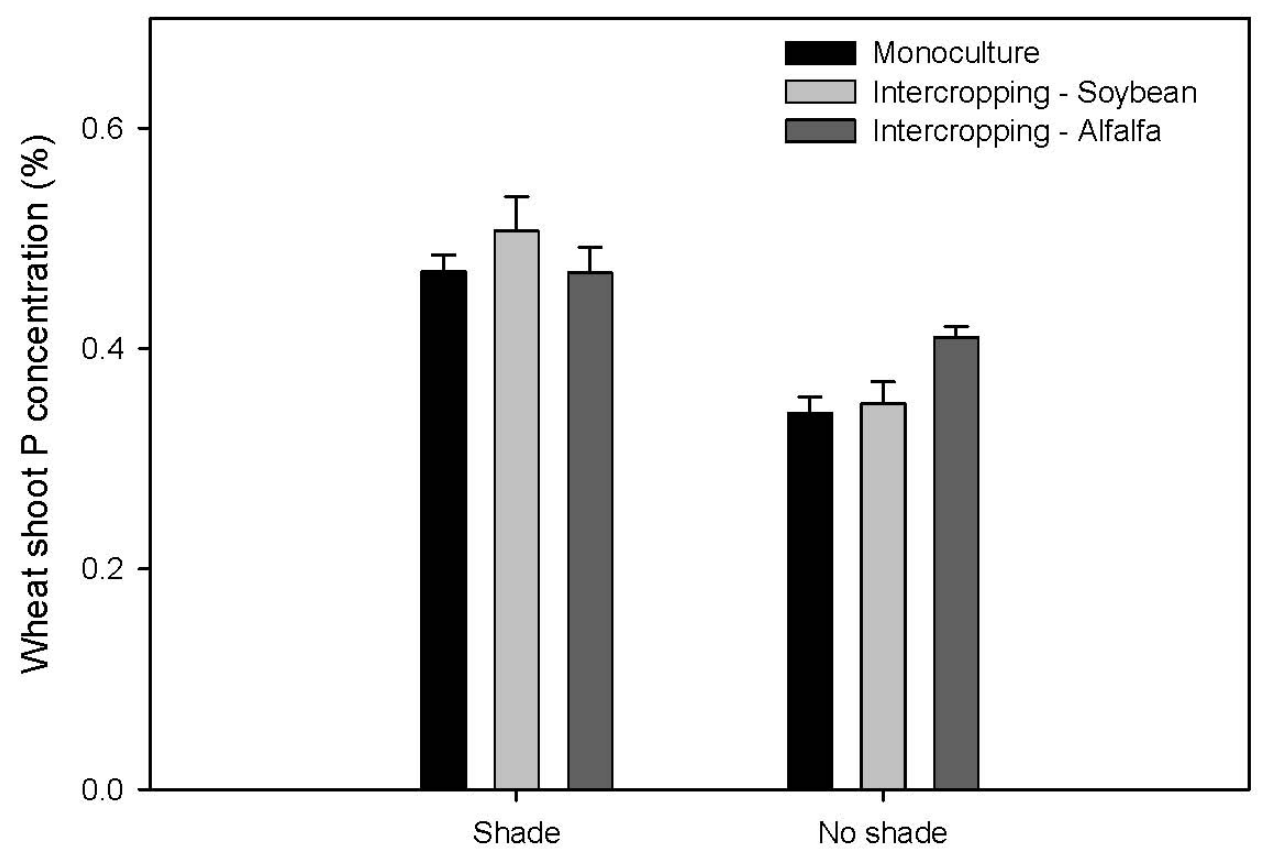

\subsection{Soil Status}

Soil parameters for the different cropping systems and under the two light levels are summarized in Table 3. There was no difference in soil extractable $\mathrm{P}$ and total $\% \mathrm{~N}$ between monocropped and intercropped treatments, although soils under monocropped wheat did show a tendency toward higher extractable $\mathrm{P}$ levels in rhizobox soils. The presence of alfalfa significantly decreased the rhizosphere soil $\mathrm{pH}$ compared to the presence of soybean when intercropped with wheat under shade $(p=0.0139$; Table 3).

Table 3. Soils status from rhizobox soils. Data are means $( \pm \mathrm{SE})$ for three samples.

\begin{tabular}{|c|c|c|c|}
\hline & \multicolumn{3}{|c|}{ Parameter } \\
\hline & $\begin{array}{c}\text { Total N } \\
(\%)\end{array}$ & $\begin{array}{c}\text { Extractable } P \\
\left(\mathrm{mg} \mathrm{Kg}^{-1} \text { dry soil) }\right.\end{array}$ & pH \\
\hline Design & \multicolumn{3}{|c|}{ Shade } \\
\hline Monocropping & $0.10 \pm 0.003 \mathrm{a}$ & $24.2 \pm 2.19 \mathrm{a}$ & $7.1 \pm 0.09 \mathrm{a}$ \\
\hline \multicolumn{4}{|l|}{ Intercropping } \\
\hline w/ soybean & $0.09 \pm 0.023 \mathrm{a}$ & $22.8 \pm 1.00 \mathrm{a}$ & $7.2 \pm 0.06 \mathrm{a}$ \\
\hline w/ alfalfa & $0.10 \pm 0.006 \mathrm{a}$ & $19.4 \pm 2.35 \mathrm{a}$ & $6.8 \pm 0.13 \mathrm{~b}$ \\
\hline & \multicolumn{3}{|c|}{ No Shade } \\
\hline Monocropping & $0.08 \pm 0.011 \mathrm{a}$ & $20.0 \pm 1.02 \mathrm{a}$ & $7.1 \pm 0.08 \mathrm{a}$ \\
\hline \multicolumn{4}{|l|}{ Intercropping } \\
\hline w/ soybean & $0.10 \pm 0.008 \mathrm{a}$ & $20.8 \pm 1.15 \mathrm{a}$ & $6.9 \pm 0.08 \mathrm{a}$ \\
\hline w/ alfalfa & $0.09 \pm 0.014 \mathrm{a}$ & $18.7 \pm 1.01 \mathrm{a}$ & $6.9 \pm 0.12 \mathrm{a}$ \\
\hline
\end{tabular}

Means within a column for Design with the same letter $(\mathrm{a}-\mathrm{b})$ are not significantly different according to a Tukey's test at $p<0.05(\mathrm{~N}=3)$. 


\section{Discussion}

\subsection{Intercropping Effects on Wheat Nutrient Acquisition and Growth}

In this controlled experiment, there were similar significant increases in $\mathrm{N}$ uptake in wheat grown with alfalfa and soybean compared to the monocropped wheat but only under shade (Figure 1). This supports reported positive effects on $\mathrm{N}$ budgets when intercropping legumes with wheat. Previous research has demonstrated that the presence of legumes under no shade can have a beneficial effect on companion wheat $\mathrm{N}$ uptake $[16,18,19]$ as well as for other associated crop species. For instance, Chu et al. [13] found that rice (Oryza sativa L.) intercropped with peanut (Arachis hypogaea L.) had significantly greater $\mathrm{N}$ content than monocropped wheat and that wheat intercropped with peanut showed yield increases of $29-37 \%$.

This increase in $\mathrm{N}$ uptake of companion crops is presumably derived from $\mathrm{N}_{2}$-fixation capacity of the legumes present. Estimates of $\mathrm{N}_{2}$-fixation rates of soybean and alfalfa are reportedly $178 \mathrm{~kg} \mathrm{~N}^{-1}$ and $350 \mathrm{~kg} \mathrm{~N} \mathrm{ha}^{-1}$ per year, respectively [20,21] reflecting a substantial amount of the required $\mathrm{N}$ for optimal growth. We found that $\mathrm{N}$ derived from atmosphere (Ndfa) ranged from no fixation to upward of $80 \%$ of total $\mathrm{N}$ derived from atmospheric N. Specifically, shaded soybean exhibited between $56 \%$ and $73 \%$ Ndfa (Figure 2).

Presumably, other abiotic factors are affecting the rates of $\mathrm{N}_{2}$-fixation within these systems. There is a species defined optimal level of light for $\mathrm{N}_{2}$-fixation, potentially linked to other site variables. Houlton et al. [22] suggested a unifying theory on Ndfa's curvilinear relationship to temperature with optimal conditions around $25{ }^{\circ} \mathrm{C}$. Phosphorus availability has been extensively shown to increase $\mathrm{N}_{2}$-fixation in greenhouse and field conditions [10,16,23,24]. Schipanski et al. [25] demonstrated that soil texture and subsequent effects on biomass may be more important for $\mathrm{N}_{2}$-fixation capacity than the previously purported soil $\mathrm{N}$ levels. We argue that these abiotic factors may be crucial parameters in predicting $\mathrm{N}_{2}$-fixation rates as shown here in shaded intercropping systems, effects that when scaled up will have significant effects on the $\mathrm{N}$ budgets of tree-based intercropping systems.

Wheat intercropped with alfalfa had significantly greater shoot $\mathrm{P}$ concentration than monocropped wheat in the no shade system (Figure 3). This was not due to differences in P acquisition zones, as monocropped wheat had a greater root area than wheat intercropped with alfalfa, higher by $\sim 20 \%$, as shown in the Winrhizo analysis (Table 2). Presumably, the presence of alfalfa had a facilitative effect on wheat $\mathrm{P}$ uptake, which has also been demonstrated in other plant species such as faba bean and maize intercrops by $\mathrm{Li}$ et al. [26]; faba bean rhizosphere acidification mobilized $\mathrm{P}$, resulting in increased availability of $\mathrm{P}$ for maize uptake. However, overall, wheat $\mathrm{P}$ concentration was higher under shade than in full sun (Figure 2). Although not significant, we measured higher extractable $\mathrm{P}$ in rhizobox soils under the shade treatment. Again however, wheat shoot biomass exhibited no significant difference between the intercropped alfalfa and monocropped wheat, suggesting that although $\mathrm{P}$ nutrition increased, this did not result in a biomass response. Past work has demonstrated yield advantages in legume intercrops due to mobilization of $\mathrm{P}$ with common bean and faba bean $[11,16]$. Similar results were expected in this experiment. But again, this lack of recorded biomass response may be due to suppressed growth under shade. 


\subsection{Light Availability and Plant Performance}

In monocropping systems, the dry weight of shoot, root, and total wheat biomass were significantly less under shade in comparison to full sunlight, as was hypothesized. Similar effects in biomass reduction under shade have also been demonstrated by Carlsson et al. [17] on Trifolium species. Although intercropping with soybean under full sun reduced wheat biomass, this did not occur under shade; the competitive ability is negated due to reduced light availability and consequently smaller biomass (Table 2).

Although the presence of alfalfa and soybean had a beneficial effect on wheat shoot $\mathrm{N}$ and $\mathrm{P}$ in the shade treatment, wheat exhibited no difference in $\mathrm{N}$ concentration between the intercropped and monocropped treatment under full sunlight. This suggests that shading may have also impacted the ability of soybean and alfalfa to access soil N, presumably due to an overall decrease in plant size, particularly the rhizosphere zone. This reduction in $\mathrm{N}$ uptake indirectly provides additional $\mathrm{N}$ for wheat to access from soil sources.

Some studies have found that light limitation can decrease the $\mathrm{N}_{2}$-fixation capabilities of legumes [2,15]. For instance, shading has been shown to decrease $\mathrm{N}_{2}$-fixation rates in white clover [10]. In contrast, a study by Chu and Robertson [27] found no impact of shading on $\mathrm{N}_{2}$-fixation in clover plants. It was hypothesized that shading of legumes would have a negative effect on $\mathrm{N}_{2}$-fixation, which would lead to decreased levels of $\mathrm{N}$ in the shade treatment. However, we found that light limitation effects on $\mathrm{N}_{2}$-fixation capacity was species specific, insofar as $\mathrm{N}_{2}$-fixation, as determined by the natural abundance method, was lower in alfalfa as compared to soybean. High levels of $\mathrm{N}_{2}$-fixation in soybean under shade may be associated with optimal micro-environment conditions, particularly temperature. However, regardless of species, intercropped wheat exhibited higher levels of $\mathrm{N}$ uptake when compared to monocropped wheat, suggesting that $\mathrm{N}_{2}$-fixation is, if not a reliable, at least a considerable source of $\mathrm{N}$ in the system.

\section{Experimental Section}

\subsection{Plant Growth Conditions}

The experiment was conducted under greenhouse conditions at the University of Toronto Scarborough greenhouse facilities in Southern Ontario (Toronto, Ontario). The average temperature in the greenhouse was $24.91{ }^{\circ} \mathrm{C}$ and the average humidity was $61.78 \%$. The three plant species investigated include durum wheat (Triticum turgidum durum) and the legumes soybean (Glycine max L. Merr.) and alfalfa (Medicago sativa). Seeds of soybean and alfalfa were sterilized with $6 \% \mathrm{H}_{2} \mathrm{O}_{2}$ and $3 \% \mathrm{Ca}(\mathrm{ClO})_{2}\left(3 \mathrm{~g} \mathrm{Ca}(\mathrm{ClO})_{2}\right.$ in $100 \mathrm{ml}$ of distilled water) for 10 minutes, respectively, followed by rinsing four times with distilled water. Seed of soybean were germinated in Petri dishes on filter papers, while seeds of alfalfa were germinated in vermiculite. After sterilization, Petri dishes with seeds were placed in a cold room overnight. Dishes were then wrapped in aluminum foil to protect from illumination and placed horizontally in the greenhouse for 7 days. Dishes were uncovered and exposed to light 4 days after germination. All seedlings were pre-cultured in a hydroponic system in order to generate roots with a large enough mass to cover the rhizoboxes. 
Prior to transfer to the hydroponic system, alfalfa seedlings were inoculated with Sinorhizobium meliloti Rm1021 and soybean seedlings were inoculated with Bradyrhizobium japonicum. Continuous aeration was provided using air pumps and thin tubes situated below the surface of the nutrient solutions. After inoculation alfalfa and soybean seedlings were transferred to buckets containing $0.7 \mathrm{mM} \mathrm{K}_{2} \mathrm{SO}_{4}, 1 \mathrm{mM} \mathrm{MgSO} 4,1.65 \mathrm{mM} \mathrm{CaCl}_{2}, 9 \mu \mathrm{M} \mathrm{Fe}^{3+}, 5 \mu \mathrm{M} \mathrm{H}_{3} \mathrm{BO}_{3}, 7.4 \mu \mathrm{M} \mathrm{MnSO}, 1.08 \mu \mathrm{M}$ $\mathrm{ZnSO}_{4}, 1.26 \mu \mathrm{M} \mathrm{CuSO}_{4}, 0.1 \mu \mathrm{M} \mathrm{Na}_{2} \mathrm{MoO}_{4}, 30 \mu \mathrm{mol} \mathrm{KH}_{2} \mathrm{PO}_{4}$. Nutrient solutions for alfalfa and soybeans were changed every 7 days. For an $\mathrm{N}$ source before nodulation, $2 \mathrm{mM}$ urea were added for the first two weeks. Note, no nitrates were added to the legume solutions in order to minimize inhibitory effects on nodulation.

Durum wheat seeds were sterilized with $6 \% \mathrm{H}_{2} \mathrm{O}_{2}$ for 10 minutes followed by rinsing with distilled water. Seeds, set on mesh, were then transferred to a hydroponic culture system, into $7 \mathrm{~L}$ buckets containing $0.7 \mathrm{mM}$ of $\mathrm{K}_{2} \mathrm{SO}_{4}, 1 \mathrm{mM} \mathrm{MgSO}_{4}, 4 \mu \mathrm{M} \mathrm{H}_{3} \mathrm{BO}_{3}, 1.65 \mathrm{mM} \mathrm{CaCl}_{2}, 1 \mu \mathrm{M} \mathrm{ZnSO}$, $6 \mu \mathrm{M}$

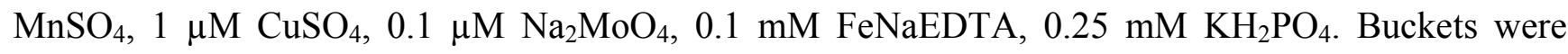
covered for one week until germination. Wheat plants were grown with $\mathrm{KNO}_{3}$ levels representing sufficiency ( $20 \mu \mathrm{mol} \mathrm{N}$ per seedling). Nutrient solutions were changed every $3-4$ days. At the transplanting to the rhizoboxes stage (3 weeks from germination), 3 representative wheat, soybean and alfalfa plantlets were harvested for initial biomass measurements.

\subsection{Steady-State Supply of Nitrogen}

Nitrogen additions for pre-contact wheat were supplied exponentially to a total level of $20 \mu \mathrm{mol} \mathrm{N}$ per seedling. Exponential additions were employed to avoid early toxicity and to match nutrient supply with growth. Nutrient applications were calculated with the equations (see [28]):

$$
N_{T}=N_{S}\left(e^{r t}-1\right)
$$

where $r$ was the relative addition rate required to increase $N S$ (the initial level of $\mathrm{N}$ content in plant) to a final level of $N_{T}+N s$. The amount $N s$ was determined by analysis of seedlings before fertilization. As we established pre-determined $\mathrm{N}$ target levels $\left(N_{T}\right), r$ is determined for the number of applications $(t=8)$. Amount of $\mathrm{N}$ for each application was determined by:

$$
N=N_{S}\left(e^{r t}-1\right)-N_{t-1}
$$

where $N_{t-1}$ was the cumulative amount of $\mathrm{N}$ up to and including the last application. Additions increased exponentially over 3 weeks with additions every 3 days.

\subsection{Experimental Design}

Interactions between wheat and legumes were investigated using a device based on the rhizobox design by Hinsinger and Gilkes [29] and Casarin et al. [30]. This device consists of a soil filled mesh bag sandwiched between two plastic plates. The plants were attached to either side of the soil filled bag. The soil in the rhizobox device was supplied with water through a filter paper wick connected to a reservoir at the bottom of the container. This device allowed the plant species to take up nutrients and interact with the soil while root mats remained separated from the soil by the mesh. It also allows for easy collection of soil from the rhizosphere for analysis. Soils were a P sufficient topsoil [extractable 
$\mathrm{P}=21 \mathrm{mg} \mathrm{kg}{ }^{-1}$ dry soil] collected from the University of Toronto's Koffler Scientific Reserve at Jokers Hill. The experimental soil was air dried and sieved at $2 \mathrm{~mm}$ to remove gravel and debris. The soil was then moistened with distilled water. Forty-six grams of soil (bulk density $1.15 \mathrm{~g} \mathrm{~cm}^{-1}$ ) were placed into the $40 \mathrm{~cm}^{3}$ rhizobox in order to obtain a soil thickness of $2 \mathrm{~mm}$. Roots were spread out in order to maximize contact with the soil. In the intercropping treatment, one soybean and one wheat plant were planted onto either side of the soil containing mesh bag, thus employing an additive design. For alfalfa, we used two plants per rhizobox to achieve a similar rhizosphere zone as the soybean and mimic more natural densities. In the monocropping treatment, only wheat was planted onto one side of the soil. The whole plot treatments consisted of two light levels representing no shade plants (full sunlight) and shaded plants (50\% sunlight). Shade canopies were constructed in the greenhouse with shade cloth at $50 \%$ on all four sides and top of a $1 \mathrm{~m}^{3}$ box. Plants remained in contact with the soil under shade or no-shade treatments for 16 days after which they were harvested for analysis.

\subsection{Plant and Soil Analysis}

Plant tissue was dried in an oven at $60{ }^{\circ} \mathrm{C}$ for 4 days. Pre and post contact root, shoot and leaf biomass were determined for each species $(\mathrm{N}=3)$. After contact in the rhizobox, total length and area of roots were determined using measurements by WinRhizo software (Regent Instruments Inc., Quebec, Canada). Wheat $\mathrm{P}$ concentration of shoot and root tissues were assessed after contact in each treatment by digestion and spectrophotometry. Soil available $\mathrm{P}$ was determined with the Olsen $\mathrm{P}$ method. Total $\mathrm{N}$ in plants (shoots and roots) and soil was determined with the Dumas method using a LECO FP428. The soil $\mathrm{pH}$ was measured in 1:5 soil to water solution using a $\mathrm{pH}$ meter.

\section{5. $\mathrm{N}_{2}$-Fixation Measurements}

${ }^{15} \mathrm{~N}$ natural abundance method was used to detect fixed $\mathrm{N}$ in soybean and alfalfa individuals. The plant tissue was oven-dried at $70{ }^{\circ} \mathrm{C}$ and milled into fine powder in a rotating ball bearing mill. The ${ }^{15} \mathrm{~N} /{ }^{14} \mathrm{~N}$ isotope ratio $\left(\%{ }^{15} \mathrm{~N}\right)$ was determined by a Stable Isotope Ratio Mass Spectrometer (Thermo Finnigan, Bremenm, Germany) coupled to an Elemental Analyzer (Carlo Erba CHNS-O EA1108-Italy). The proportion of ${ }^{15} \mathrm{~N}$ derived from the sample deviating from ${ }^{15} \mathrm{~N}$ in atmosphere was calculated as [31]:

$$
{ }^{15} \mathrm{~N}_{\mathrm{x}}(\% \mathrm{o})=\left[\left(\%{ }^{15} \mathrm{~N}_{\mathrm{x}} / \%{ }^{15} \mathrm{~N}_{\mathrm{a}}\right)-1\right] \times 1000
$$

where ${ }^{15} \mathrm{~N}_{\mathrm{x}}$ and $\%{ }^{15} \mathrm{~N}_{\mathrm{a}}$ are the percentages of ${ }^{15} \mathrm{~N}$ in the sample and in the air $(0.3663 \%$; [32]), respectively. Percentage of $\mathrm{N}$ derived from atmosphere $(\% \mathrm{Ndfa})$ was established based on calculations employing internal ${ }^{15} \mathrm{~N}$ of inoculated soybean and alfalfa and of non-inoculated reference plants. The percentage of $\mathrm{N}$ derived from atmosphere out of total $\mathrm{N}$ in the sample was calculated as:

$$
\left.\left.\% \mathrm{Ndfa}=\left[{ }^{15} \mathrm{~N}_{\mathrm{r}}-{ }^{15} \mathrm{~N}_{\mathrm{x}}\right) /{ }^{15} \mathrm{~N}_{\mathrm{r}}-{ }^{15} \mathrm{~N}_{\mathrm{fr}}\right)\right] \times 100 \%
$$

where ${ }^{15} \mathrm{~N}_{\mathrm{r}}$ is the ${ }^{15} \mathrm{~N}$ value from the reference, ${ }^{15} \mathrm{~N}_{\mathrm{x}}$ is the value from the treatment sample and ${ }^{15} \mathrm{~N}_{\mathrm{fr}}$, values for individuals grown in $\mathrm{N}$-free solution (Alfalfa $=-0.92 \%$; Soybean $=-0.80 \%$ ) was determined from the literature [33,34]. 


\subsection{Statistical Analysis}

Biomass (shoot and root) and $\mathrm{P}$ and $\mathrm{N}$ concentrations and content data were subjected to analysis of variance using a general linear model (PROC GLM) in SAS version 8.0 (SAS Institute Inc. Cary, NC, USA). In the case of a significant F-test, treatment means were compared using a Tukey's HSD test. T-tests were used to test for differences between $\delta^{15} \mathrm{~N}$ values of $\mathrm{N}_{2}$-fixing (inoculated soybean and alfalfa) and $\delta^{15} \mathrm{~N}$ of the reference [non-fixer (non-inoculated soybean and alfalfa)] in order to meet the criteria for the natural abundance method. Normality was confirmed with using the Shapiro-Wilk test. The level of significance was set to $p \leq 0.05$ for statistical tests.

\section{Conclusions}

In this model tree-crop system, intercropping wheat and alfalfa had beneficial effects on wheat $\mathrm{N}$ and $\mathrm{P}$ uptake. However, although intercropping with soybean demonstrated a positive effect on wheat $\mathrm{N}$ uptake, we report a negative impact on biomass production. This suggests that simultaneous cultivation with wheat can provide an intercrop advantage but specifically with alfalfa. Of particular interest in this study were other abiotic stresses. We examined light limitations on wheat performance when intercropped with legumes, presuming that $\mathrm{N}$ content would be reduced in the shade treatment due to suppressed $\mathrm{N}_{2}$-fixation rates. This supposition was not supported by our analysis, suggesting that legume functioning may be optimized under shady conditions, presumably via temperature modifications; however, this requires more research. Limitations associated with low light levels, presumably similar to those found near the tree component of tree-based intercropping systems, are shown to be alleviated by integrating legumes with annual cereal crops. The long-term success of this management approach will be dependent on other factors such as modified nutrient cycles and increased hydrological inputs under trees.

\section{Acknowledgments}

The authors would like to acknowledge M. Makhani, M. Charkhabi, L. Campbell, R. Croskery and C. Chen for assistance. We would like to thank D. Smith, T. Charles, T. Finan, and I. Rajcan for providing rhizobium strains. We would like to acknowledge three anonymous journal reviewers for their insightful comments on earlier versions of the manuscript. This research was funded by the Connaught Fund at the University of Toronto.

\section{References}

1. Schroth, G.; Lehmann, J.; Rodrigues, M.; Barros, E.; Macêdo, J. Plant-soil interactions in multistrata agroforestry in the humid tropics. Agrofor. Syst. 2001, 53, 85-102.

2. Swift, M.; Izac, A.; van Noordwijk, M. Biodiversity and ecosystem services in agricultural landscapes-are we asking the right questions? Agric. Ecosyst. Environ. 2004, 104, 113-134.

3. Crews, T.E.; Peoples, M.B. Can the synchrony of nitrogen supply and crop demand be improved in legume and fertilizer-based agroecosystems? Nutr. Cycl. Agorecosyst. 2005, 72, 101-120.

4. Vandermeer, J. The Ecology of Intercropping; Cambridge University Press: Cambridge, UK, 1989. 
5. Tilman, D.; Cassman, K.; Matson, P.; Naylor, R.; Polasky, S. Agricultural sustainability and intensive production practices. Nature 2002, 418, 671-677.

6. Isaac, M.; Kimaro, A. Diagnosis of nutrient imbalances with vector analysis in agroforestry systems. J. Environ. Qual. 2011, 40, 1-7.

7. Jose, S.; Gillespie, A.; Pallardy, S. Interspecific interactions in temperate agroforestry. Agrofor. Syst. 2004, 61, 237-255.

8. Thevathasan, N.; Gordon, A. Ecology of tree intercropping systems in the North temperate region: Experiences from southern Ontario, Canada. Agrofor. Syst. 2004, 61, 257-268.

9. Vandermeer, J. The ecological basis of alternative agriculture. Annu. Rev. Ecol. Syst. 1995, 26, 201-224.

10. Høgh-Jensen, H.; Schjoerring, J.; Soussana, J. The influence of phosphorus deficiency on growth and nitrogen fixation of white clover plants. Ann. Bot. 2002, 90, 745-753.

11. Li, L.; Zhang, F.; Li, X.; Christie, P.; Sun, J.; Yang, S.; Tang, C. Interspecific facilitation of nutrient uptake by intercropped maize and faba bean. Nutr. Cycl. Agroecosyst. 2003, 65, 61-71.

12. Sierra, J.; Nygren, P. Transfer of $\mathrm{N}$ fixed by a legume tree to the associated grass in a tropical silvopastoral system. Soil Biol. Biochem. 2006, 38, 1893-1903.

13. Chu, G.; Shen, Q.; Cao, J. Nitrogen fixation and $\mathrm{N}$ transfer from peanut to rice cultivated in aerobic soil in an intercropping system and its effect on soil N fertility. Plant Soil 2004, 263, 17-27.

14. Martin, R.; Voldeng, D.; Smith, D. Nitrogen transfer from nodulating soybean to maize or to nonnodulating soybean in intercrops, the ${ }^{15} \mathrm{~N}$ dilution method. Plant Soil 1991, 132, 53-63.

15. Jensen, E. Grain yield, symbiotic $\mathrm{N}_{2}$-fixation and interspecific competition for inorganic $\mathrm{N}$ in pea-barley intercrops. Plant Soil 1996, 182, 25-38.

16. Li, H.; Shen, J.; Zhang, F.; Clairotte, M.; Drevon, J.; Le Cadre, E.; Hinsinger, P. Dynamics of phosphorus fractions in the rhizosphere of common bean (Phaseolus vulgaris L.) and durum wheat (Triticum turgidum durum L.) grown in monocropping and intercropping systems. Plant Soil 2008, 312, 139-150.

17. Carlsson, G.; Palmborg, C.; Jumpponen, A.; Scherer-Lorenzen, M.; Högberg, P.; Huss-Danell, K. $\mathrm{N}_{2}$ fixation in three perennial Trifolium species in experimental grasslands of varied plant species richness and composition. Plant Ecol. 2009, 205, 87-104.

18. Li, L.; Tang, C.; Rengel, Z.; Zhang, F. Chickpea facilitates phosphorus uptake by intercropped wheat from an organic phosphorus source. Plant Soil 2003, 248, 297-303.

19. Wang, X.; Tang, C.; Guppy, C.; Sale, P. Phosphorus acquisition characteristics of cotton (Gossypium hirsutum L.), wheat (Triticum aestivum L.) and white lupin (Lupinus albus L.) under P deficient conditions. Plant Soil 2008, 312, 117-128.

20. Peoples, M.; Gault, R.; Lean, B.; Sykes, J.; Brockwell, J. Nitrogen fixation by soybean in commercial irrigated crops of central and southern New South Wales. Soil Biol. Biochem. 1995, 27, 553-561.

21. Carlsson, G.; Huss-Danell, K. Nitrogen fixation in perennial forage legumes in the field. Plant Soil 2003, 253, 353-272.

22. Houlton, B.Z.; Wang, Y.-P.; Vitousek, P.M.; Field, C.B. A unifying framework for dinitrogen fixation in the terrestrial biosphere. Nature 2008, 454, 327-331. 
23. Isaac, M.E.; Harmand, J.M.; Drevon, J.J. Growth and nitrogen acquisition strategies of Acacia senegal seedlings under exponential phosphorus additions. J. Plant Physiol. 2011, 168, 776-781.

24. Isaac, M.E.; Harmand, J.M.; Lesueur, D.; Lelon, J. Tree age and soil phosphorus conditions influence $\mathrm{N}_{2}$-fixation rates and soil $\mathrm{N}$ dynamics in natural populations of Acacia senegal. For. Ecol. Manag. 2011, 261, 582-588.

25. Schipanski, M.E.; Drinkwater, L.E.; Russelle, M.P. Understanding the variability in soybean nitrogen fixation across agroecosystems. Plant Soil 2010, 329, 379-397.

26. Li, L.; Li, S.; Sun, J.; Zhou, L.; Bao, X.; Zhang, H.; Zhang, F. Diversity enhances agricultural productivity via rhizosphere phosphorus facilitation on phosphorus-deficient soils. Proc. Natl. Acad. Sci. USA 2007, 104, 5903-5907.

27. Chu, A.; Robertson, A. The effects of shading and defoliation on nodulation and nitrogen fixation by white clover. Plant Soil 1974, 41, 509-519.

28. Timmer, V. Exponential nutrient loading: A new fertilization technique to improve seedling performance on competitive sites. New For. 1996, 13, 279-295.

29. Hinsinger, P.; Gilkes, R. Dissolution of phosphate rock in the rhizosphere of five plant species grown in an acid, P-fixing mineral substrate. Geoderma 1997, 75, 231-249.

30. Casarin, V.; Plassard, C.; Hinsinger, P.; Arvieu, J. Quantification of ectomycorrhizal fungal effects on the bioavailability and mobilization of soil $\mathrm{P}$ in the rhizosphere of Pinus pinaster. New Phytol. 2004, 163, 177-185.

31. Mariotti, A.; Germon, J.; Hubert, P.; Kaiser, P.; Letolle, R.; Tardieux, A.; Tardieux, P. Experimental determination of nitrogen kinetic isotope fractionation: Some principles; illustration for the denitrification and nitrification processes. Plant Soil 1981, 62, 413-430.

32. Mariotti, A. Natural ${ }^{15} \mathrm{~N}$ abundance measurements and atmospheric nitrogen standard calibration. Nature 1984, 311, 251-252.

33. Ledgard, S.F. Nutrition, moisture and rhizobial strain influence isotopic fractionation during $\mathrm{N}_{2}$-fixation in pasture legumes. Soil Biol. Biochem. 1989, 21, 65-68.

34. Wanek, W.; Arndt, S.K. Difference in $\delta^{15} \mathrm{~N}$ signatures between nodulated roots and shoots of soybean is indicative of the contribution of symbiotic $\mathrm{N}_{2}$-fixation to plant N. J. Exp. Bot. 2002, 53, 1109-1118.

(C) 2012 by the authors; licensee MDPI, Basel, Switzerland. This article is an open access article distributed under the terms and conditions of the Creative Commons Attribution license (http://creativecommons.org/licenses/by/3.0/). 